\title{
APLIKASI PUPUK KOMPOS ECENG GONDOK DAN MIKORIZA BERPENGARUH TERHADAP PERTUMBUHAN TANAMAN TEMBAKAU DELI (Nicotiana tabaccum L.)
}

Sri Utami*, Darmawati JS, Muhammad Yunus

Fakultas Pertanian UMSU. Medan 20238

Corresponding author: sri.utami75@yahoo.com

\begin{abstract}
ABSTRAK
Penelitian dilaksanakan pada bulan Februari 2016 sampai dengan bulan April 2016 di kebun percobaan BPTD PTP Nusantara II Jl. Kesuma No. 6 Sampali Kabupaten Deli Serdang dengan ketinggian tempat \pm 25 mdpl. Metoda penelitian ini menggunakan Rancangan Acak Kelompok (RAK) Faktorial dengan dua faktor, faktor pertama yaitu pemberian pupuk kompos eceng gondok (P) terdiri dari tiga taraf, yaitu $\mathrm{P}_{1}=300 \mathrm{~g} /$ polibeg, $\mathrm{P}_{2}=600 \mathrm{~g} / \mathrm{polibeg}$ dan $\mathrm{P}_{3}=900 \mathrm{~g} / \mathrm{polibeg}$. Faktor kedua yaitu pupuk Mikoriza (M), terdiri dari tiga taraf, yaitu $\mathrm{M}_{0}=$ tanpa pupuk Mikoriza (Kontrol), $\mathrm{M}_{1}=7,5 \mathrm{~g} /$ polibeg dan $\mathrm{M}_{2}=15 \mathrm{~g} /$ polibeg. Hasil penelitian menunjukkan bahwa aplikasi pupuk kompos eceng gondok memberikan pengaruh yang nyata terhadap tanaman tembakau Deli pada umur 8 MSPT pada parameter tinggi tanaman tertinggi $68,43 \mathrm{~cm}$, jumlah daun terbanyak 13,30 helai, luas daun terluas $172,24 \mathrm{~cm}^{2}$, diameter batang $0,92 \mathrm{~mm}$, panjang akar $26,58 \mathrm{~cm}$, berat basah tanaman 125,61 g dan berat kering tanaman 19,66 g. Aplikasi pupuk Mikoriza dan interaksi memberikan pengaruh yang tidak nyata terhadap semua parameter pengamatan yang diukur.
\end{abstract}

Keyword : Tanaman, Tembakau Deli, Pupuk Kompos Eceng Gondok, Pupuk Mikoriza

\section{PENDAHULUAN}

Tembakau adalah salah satu komoditas yang bersifat fancy product. Standar kualitasnya bergantung pada masing-masing selera pembeli. Berdasarkan kegunaannya, tembakau cerutu dikategorikan menjadi dekblad (pembalut), omblad (pembungkus), dan filler (isi) (Budiarto, 2007). Sebagai salah satu sumber pendapatan negara, tembakau mempunyai nilai ekonomi yang cukup penting karena menyumbang pendapatan negara melalui cukai. Di Indonesia, tembakau cerutu berkualitas ekspor berasal dari Sumatera, dikenal dengan nama tembakau Deli yang khusus digunakan sebagai pembalut cerutu (Erwin dan Suyani, 2000).

Tembakau Deli Sumatera merupakan jenis tembakau sebagai penghasil daun pembalut (wrapper) cerutu yang terbaik di dunia. Sampai saat ini keberadaannya sangat diminati oleh para pabrikan di Eropa Barat.
(Budiarto, 2007). Daun tembakau Deli memiliki ciri khas yaitu daun tipis dan elastis serta warna cerah dikarenakan mempunyai iklim dan tanah yang sesuai dengan pertanaman tembakau tipe pembungkus (Abdullah dan Soedarmanto, 1992).

Akhir-akhir ini dirasakan oleh semua pihak bahwa produksi tembakau Deli Sumatera merosot dalam jumlah dan kualitasnya. Penambahan bahan organik dengan menggunakan eceng gondok sebagai bahan kompos diharapkan dapat memperkaya bahan makanan bagi tanaman dan memperbaiki sifat fisik tanah akibat pencucian (Kriswiyanti dan Endah, 2009). Kompos mengandung bahan organik dalam jumlah tinggi dapat meningkatkan kelembaban retensi tanah, meningkatkan penyerapan nutrisi terutama fosfor dan struktur tanah menjadi lebih baik pertumbuhan akar dan serapan hara 
(Newton, 2014). Berdasarkan penelitian Merlina (2007), untuk meningkatkan pertumbuhan dan produktifitas suatu tanaman maka diperlukan dosis kompos yang sesuai. Pemberian dosis kompos enceng gondok dapat mempengaruhi pertumbuhan tanaman jagung. Hasil dari percobaan tanaman jagung yang diberikan perlakuan kompos enceng gondok dengan dosis $10 \%, 20 \%, 40 \%$ dan $80 \%$ ternyata yang lebih baik tumbuh yaitu pada pemberian dosis $80 \%$.

Salah satu mikroorganisme tanah yang menguntungkan sebagai pupuk hayati ialah cendawan mikoriza. Mikoriza mempunyai kemampuan berasosiasi dengan hampir 90\% tanaman (pertanian, kehutanan, perkebunan, dan tanaman pakan) dan membantu dalam meningkatkan efisiensi penyerapan unsur hara terutama fosfor pada lahan marginal. Prinsip kerja dari mikoriza ini adalah menginfeksi sistem perakaran tanaman inang, memproduksi jalinan hifa secara intensif sehingga tanaman yang mengandung mikoriza akan mampu meningkatkan kapasitas dalam penyerapan unsur hara (Hanafiah $d k k$., 2009). Cendawan mikoriza dapat meningkatkan serapan nitrogen (N) dan kalium (K). (Musfal, 2008).

\section{BAHAN DAN METODE}

Penelitian ini dilaksanakan pada bulan Februari 2016 sampai April 2016. Tempat penelitian di lahan percobaan Balai Penelitian Tembakau Deli (BPTD) PTP Nusantara II Jl. Kesuma No 6 Sampali Kabupaten Deli Serdang Sumatera Utara dengan ketinggian tempat $\pm 25 \mathrm{~m} \mathrm{dpl}$. Bahan yang digunakan dalam penelitian adalah benih tembakau Deli varietas Deli-4 BPTD PTP Nusantara II, tanah top soil, pupuk kompos eceng gondok, pupuk Hayati Mikoriza Kusuma Bioplus Agrowisata, polibeg hitam ukuran 18 × $25 \mathrm{~cm}$, terpal biru, fungisida Propamokarb Hidroklorida 722 g/l (Previcur N 722 SL), insektisida
Deltamethrin $25 \mathrm{~g} / 1$ (Decis $25 \mathrm{EC}$ ) dan air.Alat-alat yang digunakan adalah cangkul, parang babat, garu, tajak, gembor, bambu, meteran, ayakan, timbangan analitik, handsprayer, oven, alat-alat tulis, kalkulator dll.

Penelitian menggunakan Rancangan Acak Kelompok (RAK) Faktorial, dengan dua faktor yang diteliti, faktor pertama yaitu pupuk kompos eceng gondok terdiri dari tiga taraf yaitu: $P_{1}=300 \mathrm{~g} /$ polibeg, $\mathrm{P}_{2}=600$ g/polibeg, $P_{3}=900$ g/polibeg. Faktor kedua pemberian pupuk Mikoriza, terdiri dari tiga taraf yaitu: $\mathrm{M}_{0}=$ tanpa pupuk Mikoriza (Kontrol), $\mathrm{M}_{1}=7,5 \mathrm{~g} /$ polibeg dan $\mathrm{M}_{2}=15$ g/polibeg $\quad 0$ g/polibeg (kontrol), 7,5 g/polibeg, $15 \mathrm{~g} /$ polibeg. Data yang diperoleh dianalisis secara statistik dan uji beda rataan dilakukan dengan uji Duncan's Multiple Range Test (DMRT) pada taraf $5 \%$.

\section{Pelaksanaan Penelitian Pembuatan Pupuk Kompos Eceng Gondok}

Cara pembuatan kompos eceng gondok yaitu menggunakan $200 \mathrm{~kg}$ eceng gondok, 0,5 liter $\mathrm{EM}_{4}, 1 / 2 \mathrm{~kg}$ gula pasir, dan 10 liter air. Cara Pembuatan : Eceng gondok dipotong kecil-kecil agar mudah membusuk (cepat matang). Gula dilarutkan kedalam air dan campurkan larutan $\mathrm{EM}_{4}$, kemudian siram secara perlahan-lahan ke dalam tumpukan eceng gondok yang sudah dialasi dengan plastik secara merata. Tutup rapat tumpukan eceng gondok dengan plastik. Selama proses penghancuran pupuk organik eceng gondok diaduk setiap 2 hari sekali. Pada hari ke 8 - 12 kompos telah matang, apabila dibuka nampak ditumbuhi jamur berwarna putih dan apabila dipegang terasa hangat. Kompos ini sudah bisa digunakan tetapi belum hancur seluruhnya. Pada hari ke 21 kompos sudah matang sempurna dan siap digunakan. 


\section{Persiapan Areal dan Pembuatan Naungan}

Areal dibersihkan dari sampah dan gulma, kemudian lahan diratakan sehingga duduk polibeg nantinya dapat tegak. Pembibitan tembakau membutuhkan naungan karena tanaman tembakau Deli tidak dapat menerima sinar matahari secara langsung (100\%). Naungan dibuat dari tiang bambu dan terpal biru sebagai atapnya. Naungan dibuat dengan ketinggian $1,75 \mathrm{~m}$ pada bagian timur dan $1,5 \mathrm{~m}$ pada bagian barat. Apabila terjadi hujan maka dapat mengalir pada ketinggian yang rendah dan jatuh pada aliran drainase yang telah dibuat.

\section{Persiapan Media Tanam}

Media tanam menggunakan top soil (kedalaman 20-30 cm). Tanah yang digunakan harus memiliki tekstur yang baik, gembur, serta bebas kontaminasi (hama dan penyakit, pelarut, residu, dan bahan kimia). Lalu tanah diayak dengan ayakan 10 mesh. Proses pengayakan bertujuan untuk membebaskan media tanam dan sisa-sisa kayu, batuan kecil dan material lainnya.

\section{Pengisian Polibeg}

Polibeg yang digunakan adalah polibeg hitam kecil ukuran $18 \mathrm{~cm}$ x $25 \mathrm{~cm}$ dengan berat $1,2 \mathrm{~kg}$. Polibeg diisi dengan tanah top soil yang sebelumnya telah diayak. Pada saat pengisian tanah, polibeg diguncang untuk memadatkan tanah. Polibeg diisi dengan media tanam sehingga ketinggian 1 $\mathrm{cm}$ dari bibir polibeg dan disiram dengan air sampai jenuh sebelum dilakukan penanaman.

\section{Aplikasi Pupuk Kompos Eceng Gondok}

Aplikasi kompos eceng gondok dilakukan 2 minggu sebelum pindah tanam dengan mencampurkan kompos eceng gondok dengan media tanam yang ada di polibeg sesuai dengan masing-masing perlakuan.

\section{Aplikasi Pupuk Hayati Mikoriza}

Pupuk hayati mikoriza diberikan pada tanaman Tembakau Deli setelah tanaman berumur 1 minggu setelah pindah tanam. Pemberian pupuk Hayati Mikoriza yaitu dengan menaburkan di sekeliling permukaan tanah pada tanaman tembakau deli. Sebaiknya waktu pemberian pupuk dilakukan pada pagi hari sebelum penyiraman.

\section{Penyemaian Benih}

Penyemaian dilakukan dengan cara menaburkan benih di bedengan semai siap tanam. Sebelum disemaikan benih terlebih dahulu direndam selama selama 3 hari. Hal ini berfungsi untuk mempercepat perkecambahan benih tersebut. Bedengan dibentuk dengan arah timur barat yang berukuran lebar $1 \mathrm{~m}$ panjang $2 \mathrm{~m}$ sedangkan tinggi $30 \mathrm{~cm}$. Sebelum penaburan benih dilakukan pemupukan dasar dengan pupuk kompos. Penaburan benih dilakukan dengan mencampur benih dengan abu atau pasir halus agar merata. penyemaian dilakukan selama 14 hari.

\section{Penanaman Bibit}

Penanaman bibit dilakukan dengan membuat lubang yang dibuat dengan plat tugal dan ditengah polibeg. Bibit yang ditanam terlebih dahulu harus diseleksi dan hanya bibit yang normal yang ditanam pada polibeg. Setelah itu bibit ditutup dengan tanah kembali. Sebelum penanaman sebaiknya tanah disiram terlebih dahulu sampai jenuh.

\section{Parameter Yang Diukur}

Tinggi Tanaman (cm), Jumlah Daun (helai), Luas Daun $\left(\mathrm{cm}^{2}\right)$, Diameter Batang $(\mathrm{mm})$, Panjang Akar $(\mathrm{cm})$, Berat Basah Tanaman (g), Berat Kering Tanaman (g). 


\section{HASIL DAN PEMBAHASAN}

\section{Tinggi Tanaman}

Berdasarkan sidik ragam bahwa aplikasi pupuk kompos eceng gondok pada umur 8 minggu setelah pindah tanam (MSPT) berpengaruh nyata terhadap tinggi tanaman tembakau Deli, sedangkan aplikasi pupuk mikoriza dan interaksi kedua perlakuan berpengaruh tidak nyata terhadap tinggi tanaman tembakau Deli, disajikan dalam Tabel 1.

Tabel 1. Rataan Tinggi Tanaman Tembakau

Deli $(\mathrm{cm})$ Terhadap Pemberian Pupuk Kompos

Eceng Gondok dan Pupuk Mikoriza pada Umur 8 MSPT

\begin{tabular}{ccccc}
\hline Perlakuan & $\mathrm{M}_{0}$ & $\mathrm{M}_{1}$ & $\mathrm{M}_{2}$ & Rataan \\
\hline $\mathrm{P}_{1}$ & 64,72 & 64,33 & 64,89 & $64,65 \mathrm{c}$ \\
$\mathrm{P}_{2}$ & 65,89 & 65,33 & 65,67 & $65,63 \mathrm{~b}$ \\
$\mathrm{P}_{3}$ & 68,55 & 68,44 & 68,89 & $68,63 \mathrm{a}$ \\
\hline Rataan & 66,39 & 66,04 & 66,48 & \\
\hline Keterangan & Angka yang diikuti huruf yang \\
& tidak sama pada kolom yang \\
& sama berbeda nyata menurut \\
& Uji DMRT 5\% & &
\end{tabular}

Berdasarkan Tabel 1. dapat dilihat tinggi tanaman tembakau Deli dengan aplikasi pupuk kompos eceng gondok tertinggi terdapat pada perlakuan $\mathrm{P}_{3}(68,63$ $\mathrm{cm})$ yang berbeda nyata dengan perlakuan $\mathrm{P}_{1}(64,65 \mathrm{~cm})$ dan $\mathrm{P}_{2}(65,63 \mathrm{~cm})$. Hubungan tinggi tanaman tembakau Deli dan pupuk kompos eceng gondok dapat dilihat pada Gambar 1.

Berdasarkan Gambar 1. dapat dilihat bahwa tinggi tanaman tembakau Deli membentuk hubungan linier positif dengan persamaan $\hat{y}=62,3+0,006 x$ dengan nilai $r$ $=0,92$. Dari persamaan tersebut dapat diketahui bahwa tinggi tanaman tembakau Deli mengalami peningkatan pada setiap dosis pupuk kompos eceng gondok yaitu dengan pemberian $900 \mathrm{~g} / \mathrm{tanaman}$ diperoleh tinggi tanaman tertinggi, sedangkan pada pemberian $300 \mathrm{~g} / \operatorname{tanaman}$ menunjukkan hasil tinggi tanaman terendah.

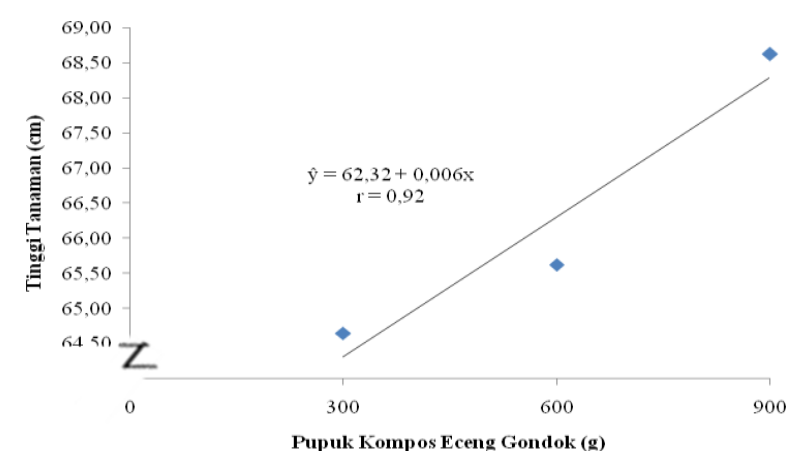

Gambar 1. Hubungan Tinggi Tanaman Tembakau Deli Terhadap pemberian Pupuk Kompos Eceng Gondok

Pemberian pupuk kompos eceng gondok berpengaruh nyata terhadap tinggi tanaman tembakau Deli pada umur 8 MSPT. Semakin banyak unsur $\mathrm{N}$ yang diterima tanaman tembakau melalui pupuk kompos maka semakin tinggi pula tinggi dari tanaman tembakau. Hal ini diduga karena pupuk kompos eceng gondok mengandung unsur hara yang dapat memacu pertumbuhan meristem apikal sehingga tanaman bertambah panjang jika dibandingkan dengan perlakuan lainnya. Poulton et al., (1989), menambahkan bahwa unsur hara menjadi komponen penting bagi tanaman khususnya unsur hara makro seperti unsur hara $\mathrm{N}, \mathrm{P}$, dan $\mathrm{K}$ dalam jumlah cukup dan berimbang karena dapat mempengaruhi pertumbuhan tanaman baik pada fase pertumbuhan vegetatif, maupun fase generatif.

\section{Jumlah Daun}

Berdasarkan sidik ragam bahwa aplikasi pupuk kompos eceng gondok pada umur 8 MSPT berpengaruh nyata terhadap jumlah daun tanaman tembakau Deli. Aplikasi pupuk mikoriza dan interaksi kedua perlakuan berpengaruh tidak nyata terhadap jumlah daun tanaman tembakau Deli, disajikan dalam Tabel 2. 
Tabel 2. Rataan Jumlah Daun Tanaman Tembakau Deli (helai) Terhadap Pupuk Kompos Eceng Gondok dan Pupuk Mikoriza pada Umur 8 MSPT

\begin{tabular}{ccccc}
\hline Perlakuan & $\mathrm{M}_{0}$ & $\mathrm{M}_{1}$ & $\mathrm{M}_{2}$ & Rataan \\
\hline $\mathrm{P}_{1}$ & 12,56 & 12,67 & 13,00 & $12,74 \mathrm{c}$ \\
$\mathrm{P}_{2}$ & 13,11 & 13,00 & 12,67 & $12,93 \mathrm{~b}$ \\
$\mathrm{P}_{3}$ & 13,11 & 13,22 & 13,56 & $13,30 \mathrm{a}$ \\
\hline Rataan & 12,93 & 12,96 & 13,07 &
\end{tabular}

Keterangan : Angka yang diikuti huruf yang tidak sama pada kolom yang sama berbeda nyata pada menurut Uji DMRT taraf 5\%

Berdasarkan Tabel 2. dapat dilihat bahwa jumlah daun tanaman tembakau Deli dengan aplikasi pupuk kompos eceng gondok terbanyak pada perlakuan $\mathrm{P}_{3}(13,30$ Helai) yang berbeda nyata dengan perlakuan $\mathrm{P}_{1}$ (12,74 Helai) dan $\mathrm{P}_{2}$ (12,93 Helai). Hubungan jumlah daun tanaman tembakau Deli dan pupuk kompos eceng gondok dapat dilihat pada Gambar 2.

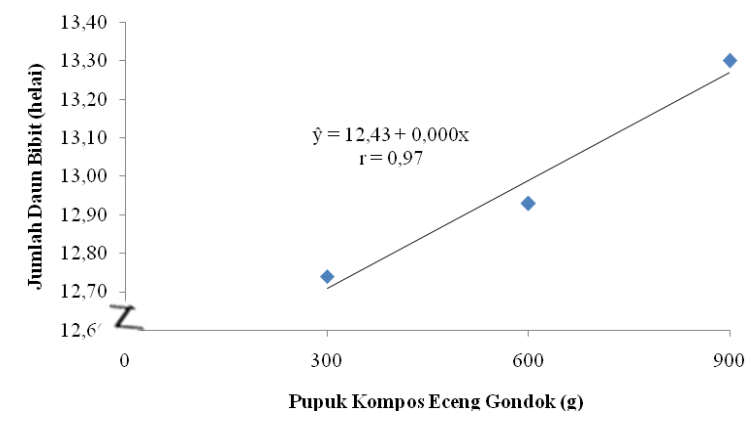

Gambar 2. Hubungan Jumlah Daun Tanaman Tembakau Deli terhadap Pemberian Pupuk Kompos Eceng Gondok

Berdasarkan Gambar 2. dapat dilihat bahwa jumlah daun tanaman tembakau Deli membentuk hubungan linier positif dengan persamaan $\hat{y}=12,43+0,000 x$ dengan nilai $\mathrm{r}=0,97$. Berdasarkan persamaan tersebut dapat diketahui bahwa jumlah daun tanaman tembakau Deli mengalami peningkatan pada setiap dosis pupuk kompos eceng gondok yaitu dengan pemberian $900 \mathrm{~g} /$ tanaman diperoleh jumlah daun tanaman tertinggi, sedangkan pada pemberian $300 \mathrm{~g} /$ tanaman menunjukkan hasil jumlah daun tanaman terendah.

Pemberian pupuk kompos eceng gondok berpengaruh nyata terhadap jumlah daun tembakau Deli umur 8 MSPT. Hal ini disebabkan oleh pemberian pupuk kompos eceng gondok dengan dosis $900 \mathrm{~g} /$ polibeg mampu meningkatkan jumlah daun tanaman. Karena pada dosis ini unsur hara yang paling berperan dalam meningkatkan jumlah daun adalah unsur N. Nitrogen memiliki manfaat bagi tanaman yaitu memacu pertumbuhan dan pembentukan daun dan anakan serta terbentuknya akar sehingga untuk mendapatkan pertumbuhan tanaman yang baik, harus diiimbangi dengan pemupukan yang baik. Nitrogen berperan penting dalam organ-organ pertumbuhan seperti pembentukan daun (Yanuarismah, 2012).

\section{Luas Daun}

Berdasarkan sidik ragam bahwa aplikasi pupuk kompos eceng gondok berpengaruh nyata terhadap luas daun tanaman tembakau Deli pada umur 8 MSP. Aplikasi pupuk mikoriza dan interaksi kedua perlakuan berpengaruh tidak nyata terhadap luas daun bibit tembakau Deli, disajikan dalam Tabel 3.

Tabel 3. Rataan Luas Daun Tanaman Tembakau Deli $\left(\mathrm{cm}^{2}\right)$ Terhadap Pupuk Kompos Eceng

Gondok dan Pupuk Mikoriza Pada Umur 8 MSPT

\begin{tabular}{|c|c|c|c|c|}
\hline Perlakuan & $\mathrm{M}_{0}$ & $\mathrm{M}_{1}$ & $\mathrm{M}_{2}$ & Rataan \\
\hline $\mathrm{P}_{1}$ & 150,68 & 153,00 & 159,54 & $154,41 c$ \\
\hline $\mathrm{P}_{2}$ & 163,39 & 161,89 & 163,90 & $163,06 \mathrm{~b}$ \\
\hline $\mathrm{P}_{3}$ & 168,54 & 166,96 & 181,21 & $172,24 a$ \\
\hline Rataan & 160,87 & 160,61 & 168,22 & \\
\hline Keterangan & $\begin{array}{l}\text { Angka } \\
\text { tidak san } \\
\text { berbeda } \\
\text { DMRT } 5\end{array}$ & $\begin{array}{l}\text { ang diikı } \\
\text { a pada ko } \\
\text { nyata } \\
\%\end{array}$ & $\begin{array}{l}\text { ati huruf } \\
\text { lom yang } \\
\text { menurut }\end{array}$ & $\begin{array}{r}\text { yang } \\
\text { ama } \\
\text { Uji }\end{array}$ \\
\hline
\end{tabular}

Berdasarkan Tabel 3. dapat dilihat bahwa luas daun tanaman tembakau Deli 
dengan aplikasi pupuk kompos eceng gondok terluas pada perlakuan $\mathrm{P}_{3}(172,24$ $\mathrm{cm}^{2}$ ) yang berbeda nyata dengan perlakuan $\mathrm{P}_{1} \quad\left(154,41 \mathrm{~cm}^{2}\right)$ dan $\mathrm{P}_{2}\left(163,06 \mathrm{~cm}^{2}\right)$. Hubungan luas daun tanaman tembakau Deli dan pupuk kompos eceng gondok dapat dilihat pada Gambar 3.

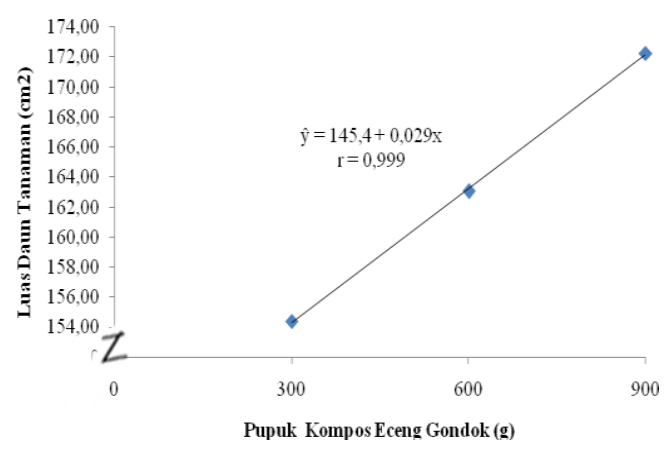

Gambar 3. Hubungan Luas Daun Tanaman Tembakau Deli Terhadap Pemberian Pupuk Kompos

Eceng Gondok

Berdasarkan Gambar 3. dapat dilihat bahwa luas daun tanaman tembakau Deli membentuk hubungan linier positif dengan persamaan $\hat{y}=145,4+0,029 x$ dengan nilai $r$ $=0,999$. Berdasarkan persamaan tersebut dapat diketahui bahwa luas daun tanaman tembakau Deli mengalami peningkatan pada setiap pemberian dosis pupuk kompos eceng gondok yaitu pemberian $900 \mathrm{~g} / \mathrm{tanaman}$ diperoleh luas daun tanaman tertinggi, sedangkan pada pemberian $300 \mathrm{~g} /$ tanaman menunjukkan hasil luas daun tanaman terendah.

Pemberian pupuk kompos eceng gondok berpengaruh nyata terhadap luas daun tembakau Deli pada umur 8 MSPT. Hal ini disebabkan oleh pemberian pupuk kompos eceng gondok dengan dosis 900 g/polibeg mampu meningkatkan luas daun tanaman. Ketersediaannya unsur hara yang sesuai dan memenuhi kebutuhan dari tanaman akan sangat membantu pertumbuhan dari tanaman itu sendiri. Pupuk organik memiliki kandungan unsur hara makro dan mikro yang dibutuhkan tanaman, tetapi kandungan atau kadar dari unsur-unsur tersebut tergolong rendah, oleh karena itu aplikasinya ke tanaman harus dalam jumlah yang banyak (Rauf et al., 2000). Pada penelitian ini jelas terlihat bahwa semakin tinggi perlakuan pupuk yang diberikan maka semakin banyak jumlah daun dan luas daun tanaman tembakau tersebut.

\section{Diameter Batang}

Berdasarkan sidik ragam bahwa aplikasi pupuk kompos eceng gondok berpengaruh nyata terhadap diameter batang tanaman tembakau Deli pada umur 8 MSPT, sedangkan aplikasi pupuk mikoriza dan interaksi kedua perlakuan berpengaruh tidak nyata terhadap diamater batang, disajikan dalam Tabel 4.

Tabel 4. Rataan Diameter Batang Tanaman

Tembakau Deli (mm) Terhadap Pupuk Kompos

Eceng Gondok dan Pupuk Mikoriza pada Umur 8 MSPT

\begin{tabular}{ccccc}
\hline Perlakuan & $\mathrm{M}_{0}$ & $\mathrm{M}_{1}$ & $\mathrm{M}_{2}$ & Rataan \\
\hline $\mathrm{P}_{1}$ & 0,91 & 0,89 & 0,88 & $0,89 \mathrm{c}$ \\
$\mathrm{P}_{2}$ & 0,91 & 0,88 & 0,90 & $0,90 \mathrm{~b}$ \\
$\mathrm{P}_{3}$ & 0,92 & 0,92 & 0,93 & $0,92 \mathrm{a}$ \\
\hline Rataan & 0,91 & 0,90 & 0,90 \\
\hline Keterangan : & Angka yang diikuti huruf yang \\
\multicolumn{5}{c}{ tidak sama pada kolom yang sama } \\
\multicolumn{5}{c}{ menurut Uji DMRT 5\% }
\end{tabular}

Berdasarkan Tabel 4. Dapat dilihat diameter batang tanaman tembakau Deli dengan aplikasi pupuk kompos eceng gondok tertinggi terdapat pada perlakuan $\mathrm{P}_{3}$ $(0,92 \mathrm{~mm})$ yang berbeda nyata dengan perlakuan $\mathrm{P}_{1}(0,89 \mathrm{~mm})$ dan $\mathrm{P}_{2}(0,90 \mathrm{~mm})$. Hubungan diameter batang tanaman tembakau Deli dan pupuk kompos eceng gondok dapat dilihat pada Gambar 4. 


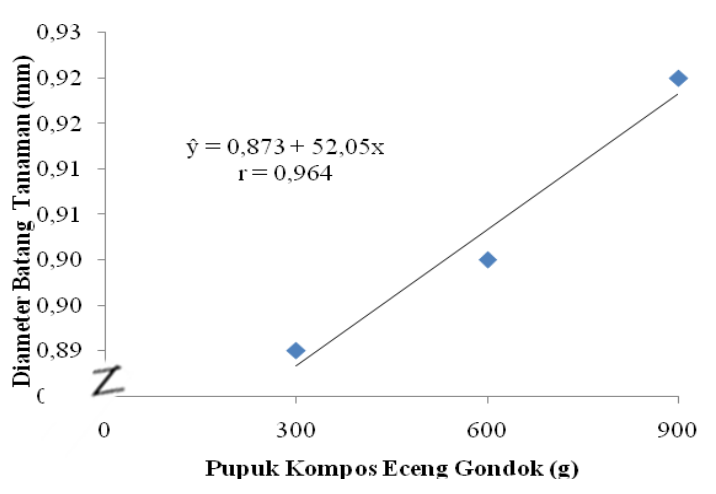

Gambar 4. Hubungan Diameter Batang Tanaman Tembakau Deli Terhadap Pemberian Pupuk Kompos Eceng Gondok

Berdasarkan Gambar 4. dapat dilihat bahwa diameter batang tanaman tembakau Deli membentuk hubungan linier positif dengan persamaan $\hat{y}=0,873+52,05$ dengan nilai $r=0,964$. Berdasarkan persamaan tersebut dapat diketahui bahwa diameter batang tanaman tembakau Deli mengalami peningkatan pada setiap dosis pupuk kompos eceng gondok yaitu dengan pemberian $900 \mathrm{~g} / \mathrm{tanaman}$ diperoleh diameter batang tanaman tertinggi, sedangkan pada pemberian $300 \mathrm{~g} /$ tanaman menunjukkan hasil diameter batang tanaman terendah.

Pemberian pupuk kompos eceng gondok berpengaruh nyata terhadap diameter batang daun tembakau Deli pada umur 8 MSPT. Hal ini disebabkan oleh pemberian pupuk kompos eceng gondok dengan dosis 900 g/polibeg mampu meningkatnya ukuran batang tanaman. Karena pada dosis ini unsur hara yang paling berperan dalam meningkatkan ukuran batang adalah Unsur N. Bertambahnya ukuran diameter batang menunjukkan bahwa berperannya unsur $\mathrm{N}$ bagi pertumbuhan tanaman terutama pada jaringan meristematik. Unsur nitrogen berperan dalam meningkatkan perkembangan batang baik secara horizontal maupun vertikal (Yulius, Pituati dan Andayani, 2009).

\section{Panjang Akar}

Berdasarkan sidik ragam bahwa aplikasi pupuk kompos eceng gondok berpengaruh nyata terhadap panjang akar tanaman tembakau Deli, sedangkan untuk aplikasi pupuk mikoriza dan interaksi kedua perlakuan berpengaruh tidak nyata terhadap panjang akar tanaman tembakau Deli, disajikan dalam tabel 5.

Tabel 5. Rataan Panjang akar Tanaman Tembakau Deli (cm) Terhadap Pupuk Kompos Eceng Gondok dan Pupuk Mikoriza pada umur 8 MSPT

\begin{tabular}{ccccc}
\hline Perlakuan & $\mathrm{M}_{0}$ & $\mathrm{M}_{1}$ & $\mathrm{M}_{2}$ & Rataan \\
\hline $\mathrm{P}_{1}$ & 24,84 & 25,50 & 25,12 & $25,15 \mathrm{c}$ \\
$\mathrm{P}_{2}$ & 25,91 & 25,56 & 25,83 & $25,77 \mathrm{~b}$ \\
$\mathrm{P}_{3}$ & 25,89 & 26,17 & 27,69 & $26,58 \mathrm{a}$ \\
\hline Rataan & 25,55 & 25,74 & 26,22 & \\
\hline
\end{tabular}

Keterangan : Angka yang diikuti huruf yang tidak sama pada kolom yang sama berbeda nyata menurut Uji DMRT 5\%

Berdasarkan Tabel 5. dapat dilihat panjang akar tanaman tembakau deli dengan aplikasi pupuk kompos eceng gondok tertinggi terdapat pada perlakuan $\mathrm{P}_{3}(26,58$ $\mathrm{cm})$ yang berbeda nyata dengan perlakuan $\mathrm{P}_{1}(25,15 \mathrm{~cm})$ dan $\mathrm{P}_{2}(25,77 \mathrm{~cm})$. Hubungan panjang akar tanaman tembakau Deli dan pupuk kompos eceng gondok dapat dilihat pada Gambar 5.

Berdasarkan Gambar 5. dapat dilihat bahwa panjang akar tanaman tembakau Deli membentuk hubungan linier positif dengan persamaan $\hat{y}=24,40+0,002 x$ dengan nilai $r$ $=0,994$. Berdasarkan persamaan tersebut dapat diketahui bahwa panjang akar tanaman tembakau Deli mengalami peningkatan pada setiap dosis Pupuk kompos eceng gondok yaitu dengan pemberian $900 \mathrm{~g} /$ tanaman diperoleh panjang akar tanaman tertinggi, sedangkan pada 
pemberian $300 \mathrm{~g} /$ tanaman menunjukkan hasil panjang akar tanaman terendah.

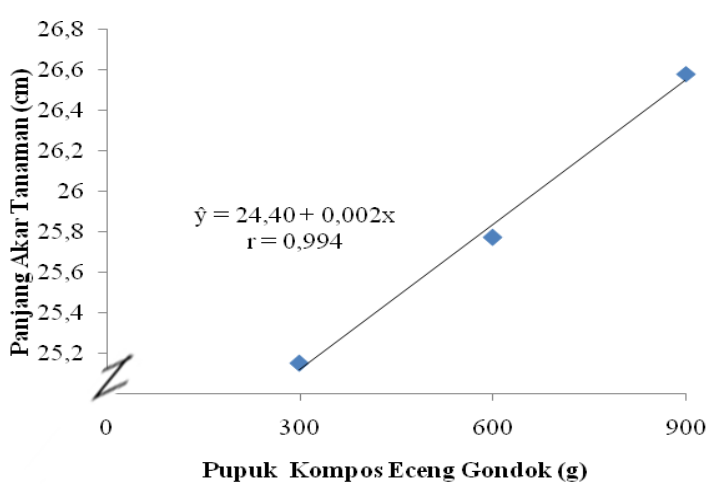

Gambar 5. Hubungan Panjang Akar Tanaman Tembakau Deli Terhadap Pemberian Pupuk Kompos Eceng Gondok

Pemberian pupuk kompos eceng gondok berpengaruh nyata terhadap panjang akar daun tembakau Deli pada umur 8 MSPT. Hal ini disebabkan oleh pemberian pupuk kompos eceng gondok dengan dosis $900 \mathrm{~g} /$ polibeg mampu meningkatkan ketersediaan bahan organik tanah pada media tanam sehingga dapat memperbaiki sifat fisik, kimia dan biologi tanah. Struktur tanah yang gembur menyebabkan aerasi berjalan lancar, sehingga perkembangan akar menjadi lebih baik yang pada akhirnya perpengaruh terhadap peningkatan volume akar akibatnya penyerapan unsur hara juga meningkat. Menurut Indranada (1986), pemberian bahan organik yang lebih akan meningkatkan produktivitas lahan karena mampu memperbaiki sifat kimia, fisik dan biologi tanah.

\section{Berat Basah Tanaman}

Berdasarkan sidik ragam bahwa aplikasi pupuk kompos eceng gondok berpengaruh nyata terhadap berat basah tanaman tembakau Deli, sedangkan untuk aplikasi pupuk mikoriza dan interaksi kedua perlakuan berpengaruh tidak nyata terhadap berat basah tanaman tembakau Deli, disajikan dalam tabel 6.
Tabel 6. Rataan Berat Basah Tanaman Tembakau Deli (g) Terhadap Pupuk Kompos Eceng Gondok dan Pupuk Mikoriza

\begin{tabular}{ccccc}
\hline $\begin{array}{c}\text { Perlakua } \\
\mathrm{n}\end{array}$ & $\mathrm{M}_{0}$ & $\mathrm{M}_{1}$ & $\mathrm{M}_{2}$ & Rataan \\
\hline \multirow{5}{c}{$\mathrm{P}_{1}$} & 105,6 & 110,7 & 115,0 & 110,47 \\
& 7 & 3 & 0 & $\mathrm{c}$ \\
$\mathrm{P}_{2}$ & 115,5 & 117,6 & 120,2 & 117,80 \\
& 7 & 3 & 0 & $\mathrm{~b}$ \\
$\mathrm{P}_{3}$ & 125,5 & 124,2 & 127,0 & 125,61 \\
\hline Rataan & 7 & 7 & 0 & $\mathrm{a}$ \\
\hline Keterangan : Angka yang diikuti huruf yang tidak \\
\multicolumn{5}{c}{ sama pada kolom yang sama berbeda } \\
nyata menurut Uji DMRT 5\%
\end{tabular}

Berdasarkan Tabel 6. dapat dilihat berat basah tanaman tembakau Deli dengan aplikasi pupuk kompos eceng gondok tertinggi terdapat pada perlakuan $\mathrm{P}_{3}(125,61$ g) yang berbeda nyata dengan perlakuan $\mathrm{P}_{1}$ $(110,47 \mathrm{~g})$ dan $\mathrm{P}_{2}(117,80 \mathrm{~g})$. Hubungan berat basah tanaman tembakau Deli dan pupuk kompos eceng gondok dapat dilihat pada Gambar 6.

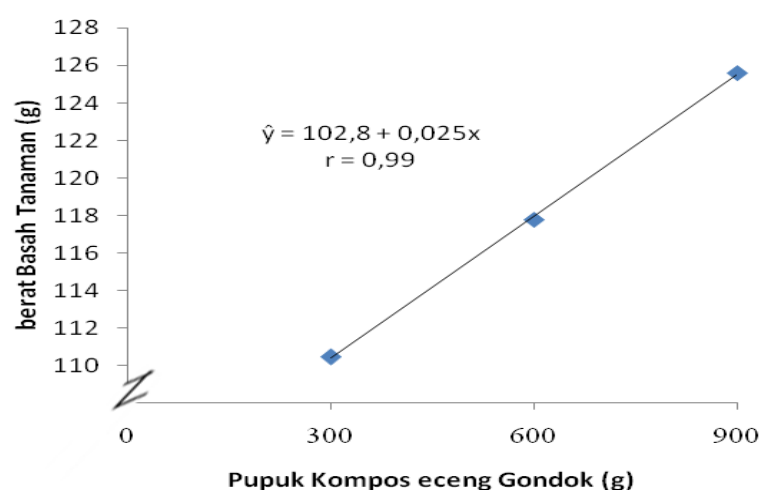

Gambar 6. Hubungan berat basah Tanaman Tembakau Deli Terhadap Pemberian Pupuk Kompos Eceng Gondok

Berdasarkan Gambar 6. dapat dilihat bahwa berat basah tanaman tembakau Deli membentuk hubungan linier positif dengan persamaan $\hat{y}=102,8+0,025 x$ dengan nilai $r$ $=0,99$. Berdasarkan persamaan tersebut dapat diketahui bahwa berat basah tanaman 
tembakau Deli mengalami peningkatan pada setiap aplikasi dosis pupuk kompos eceng gondok yaitu dengan pemberian 900 g/tanaman diperoleh berat basah tanaman tertinggi, sedangkan pada pemberian 300 g/tanaman menunjukkan hasil berat basah tanaman terendah. Pemberian pupuk kompos eceng gondok yang semakin tinggi dapat meningkatkan berat segar tanaman tembakau. Hal ini di dukung oleh Erawan et al., (2013) menyatakan bahwa apabila unsur $\mathrm{N}$ yang disuplai oleh pupuk tersedia dengan baik maka tumbuhan tersebut akan mengalami pertumbuhan yang baik.

\section{Berat Kering Tanaman}

Berdasarkan sidik ragam bahwa aplikasi pupuk kompos eceng gondok berpengaruh nyata terhadap berat kering tanaman tembakau Deli, sedangkan untuk aplikasi pupuk mikoriza dan interaksi kedua perlakuan berpengaruh tidak nyata terhadap berat basah tanaman tembakau Deli, disajikan dalam tabel 7.

Tabel 7. Rataan Berat Kering tanaman Tembakau Deli (g) Terhadap Pupuk Kompos Eceng Gondok dan Pupuk Mikoriza pada Umur 8 MSPT

\begin{tabular}{|c|c|c|c|c|}
\hline Perlakuan & $\mathrm{M}_{0}$ & $\mathrm{M}_{1}$ & $\mathrm{M}_{2}$ & Rataan \\
\hline$P_{1}$ & 16,44 & 16,71 & 17,99 & $17,05 \mathrm{c}$ \\
\hline $\mathrm{P}_{2}$ & 18,11 & 18,28 & 18,54 & $18,31 b$ \\
\hline $\mathrm{P}_{3}$ & 19,39 & 19,42 & 20,15 & $19,66 \mathrm{a}$ \\
\hline Rataan & 17,98 & 18,13 & 18,88 & \\
\hline Keterangan & $\begin{array}{l}\text { Angka } \\
\text { tidak sa } \\
\text { berbeda } \\
5 \%\end{array}$ & ang & $\begin{array}{l}\text { uti hur } \\
\text { olom ya }\end{array}$ & $\begin{array}{ll}\text { If } & \text { yang } \\
\text { ig } & \text { sama }\end{array}$ \\
\hline
\end{tabular}

Berdasarkan Tabel 7. dapat dilihat berat kering tanaman tembakau Deli dengan aplikasi pupuk kompos eceng gondok tertinggi terdapat pada perlakuan $\mathrm{P}_{3}(19,66$ g) yang berbeda nyata dengan perlakuan $P_{1}$ $(17,05 \mathrm{~g})$ dan $\mathrm{P}_{2}(18,31 \mathrm{~g})$. Hubungan berat kering tanaman tembakau Deli dan pupuk kompos eceng gondok dapat dilihat pada Gambar 7.

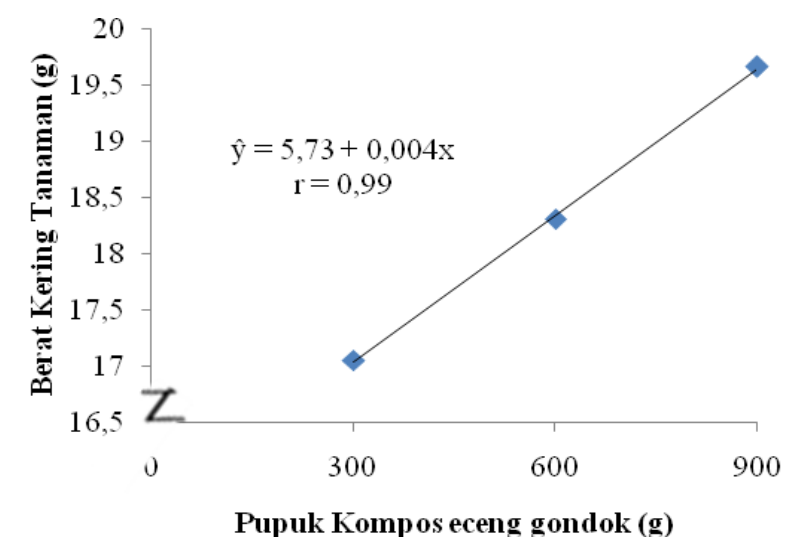

Gambar 7. Hubungan Berat Kering Tanaman Tembakau Deli Terhadap Pemberian Pupuk Kompos Eceng Gondok

Berdasarkan Gambar 7. dapat dilihat bahwa berat kering tanaman tembakau Deli membentuk hubungan linier positif dengan persamaan $\hat{y}=5,73+0,004 x$ dengan nilai $r$ $=0,99$. Berdasarkan persamaan tersebut dapat diketahui bahwa berat kering tanaman tembakau Deli mengalami peningkatan pada setiap dosis Pupuk kompos eceng gondok yaitu dengan pemberian $900 \mathrm{~g} / \mathrm{tanaman}$ diperoleh berat kering tanaman tertinggi, sedangkan pada pemberian $300 \mathrm{~g} /$ tanaman menunjukkan hasil berat kering tanaman terendah.

Aplikasi pupuk kompos eceng gondok berpengaruh nyata terhadap berat kering tanaman. Semakin tinggi $\mathrm{N}$ tersedia dalam tanah maka semakin tinggi biomasa total. Hal ini didukung oleh pendapat Fatimah

dan Budi (2008), mengatakan bahwa pertum buhan tinggi tanaman, batang, akar dan jumlah daun yang baik akan menghasilkan berat kering total tanaman yang lebih baik. Berat kering total tanaman merupakan hasil keseimbangan antara pengambilan karbondioksida dan pengeluaran oksigen secara nyata ditunjukan pada berat pada berat basah tanaman, egitu pula dengan laju fotosintesis yang berpengaruh 
terhadap berat kering tanaman dimana semakin tinggi laju fotosintesis semakin meningkat pula berat kering tanaman.

\section{SIMPULAN DAN SARAN}

\section{Simpulan}

Aplikasi pupuk kompos eceng gondok sebanyak $900 \mathrm{~g} /$ tanaman memberikan pengaruh pada tinggi tanaman tertinggi $68,63 \mathrm{~cm}$, jumlah daun terbanyak 13,30 helai, luas daun terluas $172,24 \mathrm{~cm}^{2}$, diameter batang tanaman $0,92 \mathrm{~mm}$, panjang akar $26,58 \mathrm{~cm}$, berat basah tanaman 125,61 $\mathrm{g}$ dan berat kering tanaman 19,66 g.

Aplikasi pupuk mikoriza berpengaruh tidak nyata terhadap semua parameter yang diukur. Tidak terdapat interaksi dari pemberian pupuk kompos eceng gondok dan pupuk mikoriza terhadap semua parameter yang diukur.

\section{Saran}

Untuk mendapatkan respon yang lebih baik dari penggunaan pupuk mikoriza pada tanaman tembakau Deli perlu dilakukan penelitian lanjutan dengan meningkatkan dosis.

\section{DAFTAR PUSTAKA}

Abdullah, A dan Soedarmanto. 1990. Budi daya Tembakau. CV. Yasaguna, Jaka rta. Hal 19;50.

Budiarto, H. 2007. Tantangan dan Peluang Agribisnis Tembakau Cerutu. Balittas.Litbang Pertanian.go.id

Erawan, D. Wa, O, Y. Andi, B. 2013. Pertumbuhan dan Hasil tanaman Sawi (Brassica juncea L) Pada Berbagai Dosis Pupuk Urea. Jurnal Agroteknos. 3 (1) : 19-25

Erwin dan N, Suyani. 2000. Hama Dan Penyakit Tembakau Deli. Balai Penelitian Tembakau Deli (BPTD). Medan.

Fatimah, S dan Budi, M, H. 2008. Pengaruh Komposisi Media Tanam Terhadap
Pertumbuhan dan Hasil Tanaman Sambiloto (Andrographis paniculata Nees). EMBRYO Vol 5. No.2. Fakultas Pertanian Unijoyo. Jawa Tengah.

Hanafiah, A. S., T. Sabrina, dan H. Guchi. 2009. Biologi dan Ekologi Tanah. Universitas Sumatera Utara. Medan.

Indranada. H. K. 1986. Pengelolaan Kesuburan Tanah. Bina Aksara. Jakarta.

Kriswiyanti. E dan Endah. 2009. Kinetik Hidrolisasi Selulosa dari Enceng Gondok Dengan Metode Arkenol Untuk Variabel Perbandingan Berat Eceng Gondok dan Volume Pemangkasan. Jurnal Ekuilibrium (7): 77-80.

Merlina, Meli. 2007. Pengaruh Dosis Kompos Enceng Gondok Terhadap Pertumbuhan Dan Produktifitas Tanaman Jagung (Zea mays L.). Skripsi: Jurusan Agriculture ITB.

Musfal. 2008. Efektivitas cendawan mikoriza arbuskula (CMA) terhadap pemberian pupuk spesifik lokasi tanaman jagung pada tanah Inceptisol. Tesis, Universitas Sumatera Utara. 79 hlm.

Newton, O. 2014. Effects of Water Hyacinth (Eichhornia crassipesmart. solms) Compost on Growth and Yield Parameters of Maize (Zea mays). Kenyatta University. Nairobi. Kenya.

Poulton, J.E, Romeo, J.T \& Conn, E.E. 1989. Plant Nitrogen Metabolism. Recent Advances in Phytochemistry. Vol.23. New York: Plenum Press.

Rauf, W. A., Syamsuddin, T. Sihombing, R, S. 2000. Peranan Pupuk NPK pada Tanaman Padi. Jurnal LPTP. 1 (1) 1-9 Yanuarismah. Y. 2012. Pengaruh Kompos Eceng Gondok (Eichornia crassipes Solm) Terhadap Pertumbuhan Dan Produksi Selada (Lactuca sativa $\mathrm{L}$ ). Fakultas Keguruan Dan Ilmu Pendidikan Universitas 
Muhammadiyah Surakarta.

http://eprints.ums.ac.id

Yulius, H.K., G. Pituati dan R. Andayani. 2009. Pengaruh Pemberian Air Limbah Kelapa Sawit Terhadap Pertumbuhan Vegetatif Kelapa Sawit Pada Tanah Bergambut. J. Agripeat 10 ; $65-69$. 